\title{
The Influence of Exchange Rate, International Interest Rate and Inflation Rate on Lending and Deposit Rate of Indonesia Banking Sector Through Reference Policy Rate as Intervening Variable
}

\author{
Dennij Mandeij, Vekie A. Rumate, Wensy F.I Rompas
}

\begin{abstract}
The determination of bank interest rates that consist of lending rate and deposit rate is a crucial decision for the bank business as a financial intermediary. The banks must take into account the underlying factors that influencing their interest rate determination. This research examines the influence of foreign factors and domestic factor on lending and deposit rate through a reference policy rate called BI 7-day (reverse) repo rate as an intervening variables. Foreign factors are represented by exchange rate Rupiah against USD and international interest rate called Singapore Interbank Offer Rate (SIBOR). Domestic factor is represented by inflation rate. BI 7-day (reverse) repo rate is determined by Bank Indonesia as a new reference rate for the banks to determine their lending and deposit rate. It must be noticed carefully by the banks because it shows the direction of monetary policy from Bank Indonesia to stabilize economy, especially inflation. Model of path analysis is applied to estimate the monthly series data from September 2016 to December 2018. The result shows that the exchange rate has a positive and significant influence on BI 7-day (reverse) repo rate. Inflation rate and SIBOR has negative and insignificant influence on $B I$ 7-day (reverse) repo rate. Both lending rate and deposit rate are influenced positively and significantly by BI 7-day (reverse) repo rate but the influence on lending rate is stronger than on deposit rate. Simultaneously, all foreign and domestic factors influence significantly on lending rate and deposit rate. It can be concluded that BI 7-day (reverse) repo rate as a new reference policy rate has been transmitted well to the banking sector in the form of determination of lending and deposit rate.
\end{abstract}

Keywords: BI 7-day (reverse) repo rate, exchange rate, inflation rate, interest rate, SIBOR.

\section{INTRODUCTION}

Banks have the important role in supporting an economy's progress. As business unit, bank runs an important function as financial intermediary that bridges two parties in an economy. The first one is the party who has surplus of fund and the second one is the party who has deficit of fund. As a financial intermediary, bank tries to collect fund from the party who has surplus of fund and then offer it to the party who has deficit of fund. By running this function, the banking sector will collect the idle fund and

Revised Manuscript Received on April 19, 2019.

Dennij Mandeij, Lecturer at Faculty of Economics and Business, Sam Ratulangi University, Manado, Indonesia.

Vekie A. Rumate, Lecturer at Faculty of Economics and Business, Sam Ratulangi University, Manado, Indonesia

Wensy F.I Rompas, Lecturer at Faculty of Economics and Business, Sam Ratulangi University, Manado, Indonesia allocate it to the productive purpose so that the economy can grow (Ayomi and Hermanto, 2013) [2].

When the banks try to collect the idle fund from the society, they must offer an incentive that can make people with the fund surplus are willing to put their fund in the bank. The incentive is the deposit interest rate which will be a cost component for the bank. The fund collected by the bank will be the liability for bank that consists of saving account, time deposit and demand deposit. The deposit interest rate will influence the willingness of surplus party to save their fund in the bank. The lower the deposit rate will reduce the willingness to save and the higher the deposit rate will increase the willingness to save.

After collecting the fund, the bank will try to offer it as lending to the party of fund deficit. When the bank launches the fund as lending, they will generate income in the form of lending interest rate. This rate will influence the willingness of deficit party to borrow from the bank. The higher the lending rate will reduce the willingness to borrow the fund from the bank and the lower the rate will increase the willingness to borrow the fund.

The determination of bank interest rates is a very important decision for the bank business as a financial intermediary. It will influence the internal aspects of bank business, such as liquidity and profitability. Moreover, it will also influence the macroeconomic stability, such as inflation and economic growth as the external factors of bank business. By considering the importance of bank interest rate, its determination must be based not only on the consideration of internally bank management, but also must notice the situation of money market, stability of macro economy and tendency of monetary policy.

The openness of Indonesia economy has increased the linkage between domestic and foreign money market. The changing of interest rate in the international financial center, such as Singapore money market, must be noticed carefully by the local banks in order to consider the determination of their interest rate. The different interest rate in Indonesia money market and other financial centers may affect the movement of capital in one country to another. Indonesia has implemented free movement of foreign exchange since a few decades ago so that the movement may affect the 
stability of macro economy.

The movement of capital is facilitated by the presence of foreign exchange market where the foreign exchanges are traded. When one currency is exchanged for another currency, it will determine an exchange rate or price of one currency in term of another currency (Krugman and Obstfeld, 2000) [11]. When the supply of foreign exchange decreases or the demand for foreign exchange increases, it will result a depreciation of domestic currency. On the contrary, when the supply of foreign currency increases or the demand for foreign currency decreases, it will result an appreciation of domestic currency. Indonesia has been being applied a free floating exchange rate system that makes the exchange rate is getting more volatile. It will increase the risk of asset and liabilities in foreign currency denomination. The fluctuation of exchange rate must be noticed carefully by local banks as a consideration to determine their interest rates.

As the banks are the financial institutions that operating in a macro economy, their business as financial intermediaries will be influenced by the situation of macro economy. The situation of macro economy is shown by two main indicators, the inflation rate and the changing of real GDP (Gross Domestic Product). These two main indicators may reflect the stability of macro economy. The stability of macro economy will be the external domestic factors for banks that must be considered carefully, especially in determining their interest rate.

The determination of bank interest rates in Indonesian macro economy is closely related to the direction of monetary policy applied by Bank Indonesia (BI) as central bank. Since July 2005, Bank Indonesia has applied a monetary policy framework that determines inflation rate as the main objective of monetary policy. It is called Inflation Targeting Framework (ITF) that has been being implemented until present day. The ITF is applied because there was a changing in the relation of macro-monetary variables that shown by the relation between money supply and inflation or money supply and GDP growth. Before implementing the ITF, Bank Indonesia set money supply as intermediate target that lies between the monetary instruments and the objectives of monetary policy. Since economic crisis 1998, the relation between money supply and GDP growth were getting weaker where the money supply can be no longer push GDP growth but affect strongly to the increasing of inflation rate.

When the relationship between money supply as intermediate target and GDP growth was getting weaker, the role of interest rate has been increasing in affecting inflation. This situation pushed Bank Indonesia to change the intermediate target from money supply to interest rate. This changing led to the implementation of ITF since July 2005. The main and final objective of monetary policy in this framework is to achieve and maintain stability of Rupiah value of exchange that reflected in low and stable inflation rate (Handa, 2009) [9].

In the implementation of ITF, Bank Indonesia used BI rate as a policy reference rate. As a reference rate, BI rate became a signal for the banks to determine their interest rates, both deposit and lending rate. The changing of $\mathrm{BI}$ rate was a response of monetary policy direction from BI to guarantee the actual inflation rate in line with or close to the targeted inflation rate. There was a positive relationship between $\mathrm{BI}$ rate and deposit rate; and also between $\mathrm{BI}$ rate and lending rate. It means that the changing of BI rate as a reference rate must be an effective signal of monetary policy direction to the banks in order to determine their interest rates (Mandeij, 2011) [12]. In next phase, the determination of bank interest rates is expected influencing the willingness of business sector to invest and the willingness of household sector to save and consume. At the end, the behavior of these two sectors will influence the inflation rate targeted by Bank Indonesia.

BI rate has become an important macro-monetary variable that shows the direction of monetary policy formulated by BI. Nevertheless, BI rate was not a transactional rate that adhered to the money market securities. It was just a hint for monetary operation in the form of open market operation to direct the rate of Certificate of Bank Indonesia (SBI) with the shortest maturity close to BI rate. The maturity (tenor) of SBI could be 12 months. If Bank Indonesia wants to reduce inflation rate, $\mathrm{BI}$ rate will be increased. The higher $\mathrm{BI}$ rate will be an incentive for the banks to buy Certificate of Bank Indonesia (SBI) and put their money for 12 months in Bank Indonesia. When the inflation rate is already reduced and BI wants to pushed GDP growth then BI rate will be decreased. It is expected that the banks can launch more lending to the business and household sector so they can increase capacity of production to push economic growth. But the fact, even though BI rate is already lowered but the bank money is still saved in the Bank Indonesia in the form of SBI purchase with 12 months maturity. The bank cannot instantly supply more lending to the society. They must wait until the 12 months of maturity is over to supply more lending. So, the increasing of economic growth will be delayed. It also may happen when $\mathrm{BI}$ raises $\mathrm{BI}$ rate, it will not instantly reduce inflation rate because the banks will not immediately save their money for 12 months by purchasing SBI. This situation will cause the monetary policy becoming less effective when it transmits the changing policy to the expected objective.

In order to achieve more effective monetary policy, Bank Indonesia has introduced and implemented a new reference rate since August 19, 2016. This new reference rate is known as BI 7-day (reverse) repo rate that replaced BI rate. This new rate has shorter maturity date (tenor) compared with BI rate where its maturity is counted for 7 days and its fold. Gali and Gertler (2007) [7] recognized that central banks typically employ a short-term interest rate as the policy instrument. The current values of aggregate output and inflation depend not only on the central bank's current choice of the short-term interest rate but also on the anticipated future path of this instrument. The implementation of this new reference rate is expected to influence faster the money market, the banks and business sector. It is a transactional rate because it adheres to money market securities directly. Bank Indonesia expected that this 
BI 7-day repo rate will strengthen the signal of monetary policy as reference rate for the banks and increase the effectiveness of transmission mechanism in monetary operation.

When Bank Indonesia raises BI 7-day repo rate, the banks may save their money in the Bank Indonesia for 7 days maturity or its fold (14, 21 and its sequences). With the shorter maturity, the banks can easily and quickly put and take their money from BI. So, BI will be easier to control money supply and inflation. With the shorter maturity date, BI 7-day repo rate has lower rate compared with BI rate that has longer maturity. This new reference rate is expected influencing faster the bank interest rates.

This paper will analyze the factors that influence lending rate and deposit rate which BI 7-day (reverse) repo rate is treated as an intervening variable. The factors that identified in this research are Singapore Interbank Offer Rate (SIBOR), exchange rate Rupiah against USD and domestic inflation rate. SIBOR represents international interest rate, especially from South East Asia money market. It is an external factor that reflects the movement of international fund in this region. Exchange rate is also taken into account as external factor that reflects the flowing of foreign exchange in and outside Indonesia. Indonesia inflation rate is an internal factor that reflects the fluctuation of prices of goods and services in Indonesia. These factors are considered as determinants of lending and deposit rate setting. As interest rate has become an important macromonetary variable in monetary operation, the banks must also notice carefully to the policy reference rate in determining their interest rate. So, in this research, BI 7-day repo rate will be mediating variable that lies between independent variables and dependent variables.

Specifically, this research has some objectives to achieve. First, to analyze the influence of SIBOR, exchange rate and inflation rate on BI 7-days (reverse) repo rate simultaneously and partially. Second, to analyze the influence of SIBOR, exchange rate, inflation rate and BI 7days repo rate on lending rate simultaneously and partially. Third, to analyze the influence of SIBOR, exchange rate, inflation rate and $\mathrm{BI}$ 7-days repo rate on deposit rate simultaneously and partially.

\section{LITERATURE REVIEW}

\subsection{Banks Business as Financial Intermediaries}

Banks have a very special function in economy as financial intermediaries. There are two parties in economy where the banks will bridge between them. The first party is people who have surplus of fund that called as household sector and the second one is people who have deficit of fund that called as business sector. As intermediaries, the banks will collect the fund from household sector by selling or issuing financial claims such as saving, time deposit and demand deposit. The fund collected by the bank will be supplied to the business sector as loan (Rose and Hudgins, 2010) [15].

By doing this intermediaries function, banks fulfill two functions (Saunders and Millon, 2008) [17]. The first function is the brokerage function where the banks act as an agent for the household sector as saver in providing information and transaction services. In fulfilling brokerage function, the banks play an important role by reducing transaction and information costs or imperfections between household and business sector. The second function is the asset transformation function. In acting as asset transformer, the banks issue financial claims to the household sector in order to obtain fund that will be banks' liabilities and supply it to the business sector as loan that will be banks' asset.

The existence of banks as financial intermediaries has been being allocated the idle fund from household sector to the productive purposes in business sector so that it can support and stimulate the economy to grow. As financial intermediaries, banks have important role in minimizing transaction cost, sharing the risk and eliminating asymmetric information in the form of adverse selection and moral hazard (Mishkin, 2006) [13].

Banks must generate income and spend cost in doing their business as financial intermediaries. When the banks try to collect the fund from the household sector, they must offer an attractive incentive to motivate people save their fund in the banks. The incentive is deposit or saving interest rate. The higher deposit rate will make people more interested to put their fund in the banks but make the bigger the cost of fund the bank must pay. On the contrary, the lower deposit rate will reduce the willingness of people to put their fund in the bank but make the smaller cost of fund to pay.

As the banks supply the fund collected to the business sector as loan, they will generate income as called lending rate. The corporations that borrow money from the bank must pay lending interest rate to the bank. The higher lending rate will reduce the willingness of corporation to borrow fund from the bank. On the contrary, the lower lending rate will increase the willingness of corporation to borrow from the bank.

The bank interest rates, both deposit and lending rate, are very important variables for the bank in running their business. Moreover, the rates determination will influence the progress of economy. The globalization and the competitiveness in banking business will be the factors that will influence the bank function as financial intermediaries (Siringoringo, 2012) [18]. That is why the bank interest rates determination becomes a serious concern from Bank Indonesia as central bank.

\subsection{The Interest Rate Determination}

The interest rate is the price of money expressed in percentage (Samuelson and Nordhaus, 2010) [16]. Keynes (1936) in [4] explained that the interest rate is determined in the money market. There are two components interacting in the money market, real money demand and real money supply. When they interact, it will result an equilibrium interest rate.

Real money demand is influenced by interest rate negatively and national income positively. This relationship can be expressed as real money demand function, as the following equation: 


\section{$\mathrm{L} / \mathrm{P}=f(\mathrm{r}, \mathrm{Y})$}

where $\mathrm{L}$ is nominal money demand (liquidity preference), $\mathrm{P}$ is price level, $\mathrm{r}$ is interest rate and $\mathrm{Y}$ is national income. This function can be shown graphically as seen in Fig. 2.1. Real money demand curve is a downward sloping curve that moves from the up left to the downright. It shows that when the interest rate increases, the real money demand will decrease, vice versa, cateris paribus.

Money supply is controlled by central bank as monetary authority. Because money supply is determined by central bank, so the real money supply (M/P) is drawn graphically as a vertical curve as seen in Fig. 2.1 where $\mathrm{M}$ denotes as money supply. When the central bank supplies more money and price level $(\mathrm{P})$ is constant, the real money supply will shift to the right. On the contrary, it will shift to the left when the central bank reduces money supply. The same situation may happen when there is a changing in price level. For instance, when the price level decreases with the constant money supply, the real money supply curve will shift to the right. On the contrary, when the price level increases, the real money supply will shift to the left.

The money market equilibrium happens when the real money demand $(\mathrm{L} / \mathrm{P})$ is the same as the real money supply $(\mathrm{M} / \mathrm{P})$. This equilibrium is shown graphically when the real money demand curve intersects the real money supply curve at a point as shown at point $\mathrm{E}$ in Fig. 2.1. At a given price level (P), the quantity of money demanded by society equals to the quantity of money supplied by central bank $(\mathrm{L}=\mathrm{M})$ (Blanchard, 2000) [4]. The money market equilibrium will result an equilibrium interest rate as shown as $\mathrm{r}_{\mathrm{E}}$ in Fig. 2.1.

The changing of price level $(\mathrm{P})$ with the constant money supply (M) will shift the real money supply curve (M/P). For instance, the increasing of price level with the constant money supply will lower the real money supply and cause its curve shift to the left. It will result a new equilibrium in money market with the higher new equilibrium interest rate. On the contrary, the decreasing of price level will increase the real money supply and cause its curve shift to the right. The new equilibrium will be resulted with the lower equilibrium interest rate.

In the implementation of Inflation Targeting Framework (ITF), the central bank sets a target to be the final objective of monetary policy. The target is to achieve the lower inflation rate and stable prices. To achieve the target, the central bank determines a signal interest rate that will be a reference for money market and the banks in determining their own interest rates, both deposit and lending rate. The amount of money supply will be adjusted to the reference rate that has been determined by central bank's policy. In this case, the central bank applies some instruments of monetary policy to add or reduce money supply. The determination of reference policy rate is actually showing the direction and nature of the expected monetary policy by central bank. It will then be transmitted to the financial sector and business sector.

Fig. 2.1 shows how the determination of a reference policy rate works. The central bank sets a signal rate that will be a reference for the banks at $r_{s}$. To achieve this reference rate, bank central applies the instruments of monetary policy that is aimed to change money supply according to the reference rate. For instance, when the amount of money supply is at $\mathrm{M}_{1}$, the actual interest rate is at $r_{1}$. It is higher than the signal rate $r_{s}$. The central bank must apply the monetary policy instruments that are directing money supply to add from $\mathrm{M}_{1}$ to $\mathrm{M}_{2}$. When it is happening, the real money supply will shift to the right from $\mathrm{M}_{1} / \mathrm{P}$ to $\mathrm{M}_{2} / \mathrm{P}$. It is expected to continue until achieving equilibrium point that is the signal reference rate $r_{s}$

On the other side, the actual interest rate can be lower than the signal rate. For instance, as shown in Fig. 2.1 that the actual interest rate is at $r_{2}$ that lower than the signal rate $r_{s}$. Instruments of monetary policy will be applied to reduce money supply from $M_{3}$ to $M_{2}$. So, it will shift the real money supply curve to the left from $\mathrm{M}_{3} / \mathrm{P}$ to $\mathrm{M}_{2} / \mathrm{P}$. Money market equilibrium is expected to achieve a new equilibrium point $E$ with the signal rate $r_{s}$ as a reference.

After determining the signal rate as a reference policy rate, the banks are expected to follow determining their deposit and lending rate according to the reference rate. The banks' interest rates will then be transmitted to the household and business sector in the form of consumption and investment changing. These changing are also expected to influence inflation rate to the level that was targeted by central bank.

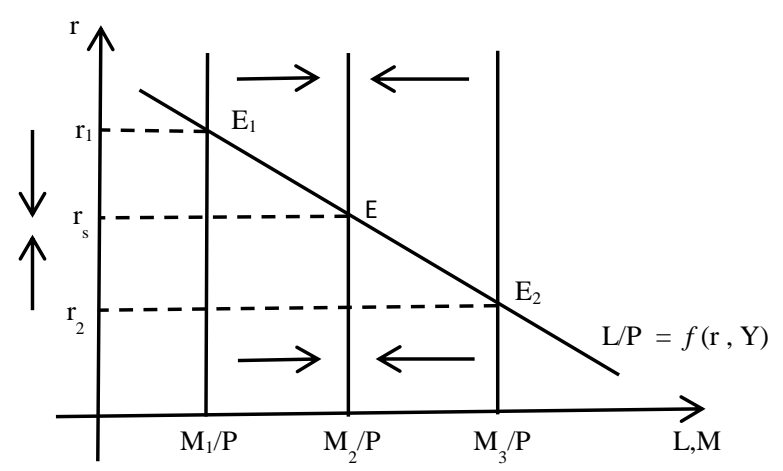

Fig. 2.1 Determination of Signal Interest Rate as Reference

When the money market mechanism works, the interest rate may fluctuate. The fluctuation of interest rate cannot be controlled fully by the banks (Ozdemir and Schmidbauer, 2014) [14]. It makes them face the risk of interest rate fluctuation. This interest rate risk is categorized as systematic risk where it can take place as the consequence of political and economic uncertainty that may affect the behavior of asset in money market.

The determination of interest rate has important role in economy. The fluctuation of interest rate may affect directly to the process and market mechanism (Ang and Bekaert, 2002) [1]. Furthermore, Dai and Singleton (2002) [6] showed that the interest rate may impact not only on the work of market mechanism but it can also change the market structure.

\section{METHODOLOGY}

The model of this research is built to be a thinking 
framework as shown in Fig. 3.1. This research examines the influence of foreign factors and domestic factor on the bank interest rates, both lending and deposit rate, through BI 7day (reverse) repo rate as intervening variable. The foreign factors used in this model are represented by international interest rate in the South East Asia region known as Singapore Interbank Offer Rate (SIBOR) and exchange rate Rupiah against US Dollar. The domestic factor is represented by inflation rate. BI 7-day (reverse) repo rate is a relatively new reference policy rate implemented by Bank Indonesia (BI) that changed BI rate as the old reference rate since August 19, 2016. The analysis applied in this research is path analysis.

Based on the structure of research model in Fig. 3.1, there will be three structural equations derived to estimate. Those equations are written as follows:

1. Structural equation 1

$\mathrm{Y}=\left(\mathrm{a}_{1} \mathrm{X}_{1} \mathrm{Y}\right) \mathrm{X}_{1}+\left(\mathrm{a}_{2} \mathrm{X}_{2} \mathrm{Y}\right) \mathrm{X}_{2}+\left(\mathrm{a}_{3} \mathrm{X}_{2} \mathrm{Y}\right) \mathrm{X}_{3}+\mathrm{E}_{1}$

2. Structural equation 2

$\mathrm{Z}_{1}=\left(\mathrm{b}_{1} \mathrm{X}_{1} \mathrm{Z}_{1}\right) \mathrm{X}_{1}+\left(\mathrm{b}_{2} \mathrm{X}_{2} \mathrm{Z}_{1}\right) \mathrm{X}_{2}+\left(\mathrm{b}_{3} \mathrm{X}_{3} \mathrm{Z}_{1}\right) \mathrm{X}_{3}+$ $\left(b_{4} \mathrm{YZ}_{1}\right) \mathrm{Y}+\mathrm{E}_{2}$

3. Structural equation 3

$\mathrm{Z}_{2}=\left(\mathrm{c}_{1} \mathrm{X}_{1} \mathrm{Z}_{2}\right) \mathrm{X}_{1}+\left(\mathrm{c}_{2} \mathrm{X}_{2} \mathrm{Z}_{2}\right) \mathrm{X}_{2}+\left(\mathrm{c}_{3} \mathrm{X}_{3} \mathrm{Z}_{2}\right) \mathrm{X}_{3}+$ $\left(c_{4} \mathrm{YZ}_{2}\right) \mathrm{Y}+\mathrm{E}_{3}$

Those equations will be estimated using ordinary least square (OLS) method to find the value of regression coefficient of each independent variable. The value of regression coefficient will be used as theoretical test that shows the association between independent (explanatory) and dependent variables. The statistics method will then be applied to find out the influence of independent variables and dependent variables simultaneously and partially (Sunyoto, 2012) [19].

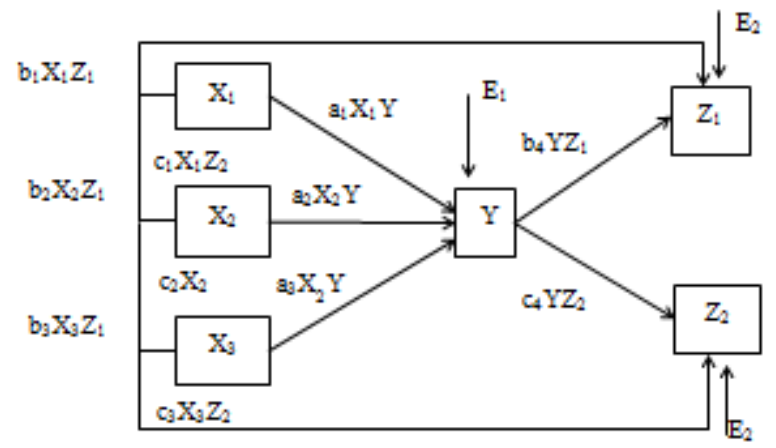

Fig. 3.1 Structure of Research Model

The structural equation 1 will be estimated to find out the influence of exchange rate Rupiah against US Dollar $\left(\mathrm{X}_{1}\right)$, SIBOR $\left(\mathrm{X}_{2}\right)$ and inflation rate $\left(\mathrm{X}_{3}\right)$ on BI 7-day (reverse) repo rate $(\mathrm{Y})$ as reference policy rate, both simultaneously and partially. The structural equation 2 will be estimated to find out the influence of exchange rate Rupiah against US Dollar $\left(\mathrm{X}_{1}\right)$, SIBOR $\left(\mathrm{X}_{2}\right)$, inflation rate $\left(\mathrm{X}_{3}\right)$ and BI 7-day (reverse) repo rate $(\mathrm{Y})$ on banks' lending rate $\left(\mathrm{Z}_{1}\right)$, simultaneously and partially. The structural equation 3 will be estimated to find out the influence of exchange rate Rupiah against US Dollar $\left(\mathrm{X}_{1}\right)$, SIBOR $\left(\mathrm{X}_{2}\right)$, inflation rate $\left(\mathrm{X}_{3}\right)$ and BI 7-day (reverse) repo rate $(\mathrm{Y})$ on banks' deposit rate $\left(Z_{2}\right)$, simultaneously and partially. Each independent variable in structural equation 1 has regression coefficient $a_{1}, a_{2}$ and $a_{3}$ for $X_{1}, X_{2}$ and $X_{3}$, respectively. In the structural equation 2, regression coefficient $b_{1}, b_{2}, b_{3}$ and $b_{4}$ are for independent variables $\mathrm{X}_{1}, \mathrm{X}_{2}, \mathrm{X}_{3}$ and $\mathrm{Y}$, respectively. In the structural equation 3 , regression coefficient $c_{1}, c_{2}, c_{3}$ and $c_{4}$ are for independent variables $\mathrm{X}_{1}, \mathrm{X}_{2}, \mathrm{X}_{3}$ and $\mathrm{Y}$, respectively. The value of $E_{1}, E_{2}$ and $E_{3}$ are calculated by subtracting the coefficient of determination $\left(\mathrm{R}^{2}\right)$ each equation from one (1 $-\mathrm{R}^{2}$ ).

The Data used in this model is monthly series from September, 2016 to December, 2018. The source of data is from Indonesia Financial Statistics (IFS) published by Bank Indonesia. Data of exchange rate is transform to natural logarithm so it can be expressed as percentage change.

\section{RESULTS AND DISCUSSION}

\subsection{The Structural Equation 1}

The structural equation 1 is estimated to find out and test the influence of exchange rate $\left(\mathrm{X}_{1}\right)$, SIBOR $\left(\mathrm{X}_{2}\right)$ and inflation rate $\left(\mathrm{X}_{3}\right)$ on $\mathrm{BI}$ 7-day (reverse) repo rate $(\mathrm{Y})$ as reference policy rate, both simultaneously and partially. The result of estimation is shown in table 4.1 as follows:

Table 4.1 The Estimation Result of Structural Equation 1

\begin{tabular}{|c|c|c|c|}
\hline Variables & Coefficient & $\boldsymbol{t}$-statistics & Probability \\
\hline $\mathrm{X}_{1}$ & 14,142 & 3,857 & 0,001 \\
\hline $\mathrm{X}_{2}$ & $-0,711$ & $-1,608$ & 0,121 \\
\hline $\mathrm{X}_{3}$ & $-0,027$ & $-0,118$ & 0,907 \\
\hline $\mathrm{R}^{2}=0,548$ & F-statistics $=9,708$ \\
$\mathrm{E}_{1}=1-0,548=0,452$ & \multicolumn{2}{l}{} \\
\hline
\end{tabular}

Source: Data processed

The coefficient of determination $\left(\mathrm{R}^{2}\right)$ resulted from structural equation 1 is 0,548 . It means that about $54 \%$ of the variations in $\mathrm{BI} 7$-day (reverse) repo rate $(\mathrm{Y})$ is explained by the exchange rate Rupiah against US Dollar $\left(\mathrm{X}_{1}\right)$, SIBOR $\left(\mathrm{X}_{2}\right)$ and inflation rate $\left(\mathrm{X}_{3}\right)$ while the rest of it about $45 \%$ explained by the factors outside the model.

In order to know the overall significance, F-test is applied. The value of F-statistics is bigger than its F-table, so it can be said that the exchange rate $\left(X_{1}\right)$, SIBOR $\left(X_{2}\right)$ and inflation rate $\left(\mathrm{X}_{3}\right)$ influence simultaneously on BI 7-day (reverse) repo rate $(\mathrm{Y})$ as reference policy rate. Gujarati (2003) [8] said that there is a close relationship between $F$ and $R^{2}$ where the larger the $R^{2}$, the greater the $F$ value.

The exchange rate partially has a positive and significant influence on BI 7-day (reverse) repo rate with the value of coefficient as direct influence is 14,142 . It shows that when Rupiah depreciated against US Dollar, Bank Indonesia will increase the reference policy rate, vice versa. This result is suitable with the hypothesis. The increasing of BI 7-day (reverse) repo rate is intended to prevent the more purchase of US Dollar in the foreign exchange market. This action will also reduce the speculation motive from market actors by buying more US Dollar and selling Rupiah in the foreign exchange market. The higher BI 7-day (reverse) repo rate will make US Dollar less attractive to buy. The action to increase BI 7-day (reverse) repo rate is clearly to stabilize 
the value of exchange rate Rupiah against US Dollar. On the contrary, when Rupiah appreciates against US Dollar, BI 7day (reverse) repo rate will decrease.

The variable Singapore Interbank Offer Rate (SIBOR) that representing international interest rate influences negatively but not significantly on BI 7-day (reverse) repo that SIBOR influences positively on BI 7-day (reverse) repo rate. SIBOR is an average interest rate offered by Singapore banking as a financial center in South East Asia region for borrowing and lending. In fact, SIBOR showed a relatively stable rate and smooth changing in the Singapore money market. It causes the influence on BI 7-day (reverse) repo rate is not significant. This result shows that the main concern of Bank Indonesia is not heavily on the changing of SIBOR but on the changing of exchange rate. day (reverse) repo rate but this influence is not significant partially. The hypothesis for these two variables truly said that there is a positive relationship between them. The fluctuation of inflation rate must be taken into account as priority consideration in determining the reference policy rate because the inflation rate is the main objective of monetary policy. Nevertheless, the result shows a surprising thing in which the inflation rate has no significant influence on BI 7-day (reverse) repo rate. It may take place because for this research period, Bank Indonesia was able to manage and control the inflation rate keeps low and stable. Bank Indonesia can perform an effective monetary policy in the framework of inflation targeting that successfully achieves the actual interest rate close to the targeted rate. With the low inflation rate and smooth fluctuation, the changing of inflation rate has no significant influence on BI 7-day (reverse) repo rate as reference policy rate.

\subsection{The Structural Equation 2}

The structural equation 2 is estimated to find out and test the influence of exchange rate $\left(\mathrm{X}_{1}\right)$, SIBOR $\left(\mathrm{X}_{2}\right)$, inflation rate $\left(\mathrm{X}_{3}\right)$ and $\mathrm{BI} 7$-day (reverse) repo rate $(\mathrm{Y})$ on the banks' lending rate $\left(\mathrm{Z}_{1}\right)$, both simultaneously and partially. The result of estimation is shown in table 4.2 as follows:

Table 4.2 The Estimation Result of Structural Equation 2

\begin{tabular}{|c|c|c|c|}
\hline Variables & Coefficient & $\boldsymbol{t}$-statistics & Probability \\
\hline $\mathrm{X}_{1}$ & $-2,319$ & $-2,126$ & 0,044 \\
\hline $\mathrm{X}_{2}$ & $-1,239$ & $-11,387$ & 0,000 \\
\hline $\mathrm{X}_{3}$ & $-0,054$ & $-0,995$ & 0,330 \\
\hline $\mathrm{Y}$ & 0,156 & 3,278 & 0,003 \\
\hline $\begin{array}{l}\mathrm{R}^{2}=0,966 \\
\mathrm{E}_{2}=1-0,966=0,034\end{array}$ & F-statistics $=164,577$ \\
\hline
\end{tabular}

\section{Source: Data processed}

The value of coefficient of determination $\left(\mathrm{R}^{2}\right)$ in this model is 0,966 . It means that about $96 \%$ of the variations in the lending rate is explained by the exchange rate Rupiah against US Dollar, SIBOR, inflation rate and BI 7-day (reverse) repo rate while the rest of it about $3 \%$ explained by the factors outside the model. The value of $\mathrm{R}^{2}$ in this model is very high that shows the goodness of fit of the regression line which is better to fit the set of data used. rate. This result is not suitable with the hypothesis that states

The variable inflation rate influences negatively on BI 7-

The overall significance of this model shows the exchange rate Rupiah against US Dollar, SIBOR, inflation rate and BI 7-day (reverse) repo rate simultaneously influence the lending rate. This overall influence is very significant on the banks' lending rate as seen at the value of F-statistics that far above its F-table. All these explanatory variables are very important factors for the banks in determining their lending rate.

The test of hypothesis partially is applied to find out the influence of each explanatory variable on the lending rate. The $t$-test is applied to find out the result. In the structural equation 2 , the inflation rate is the only explanatory variable that has no significant influence on the lending rate. It is expected as hypothesis said that when there is an increasing of inflation rate, the banks should increase their lending rate in order to prevent the inflation. On the contrary, the decreasing of inflation rate will cause the banks to decrease their lending rate to supply more loans. Nevertheless, the result has an opposite direction and insignificantly influence. Chowdhury (2012) [5] found the same result as this research which states that there is no significant relationship between the inflation rate and lending rate. It can be explained that for this research period, the inflation rate shows the low rate and stable. The inflation rate achieved in this period is close to the targeted inflation announced by Bank Indonesia. So, the monetary policy applied by Bank Indonesia is effective to achieve the low rate of inflation and maintain the stable prices as its ultimate objective. The smooth and small changing of inflation rate in this period has no significant influence on the banks' lending rate.

The partial test applied to the influence of exchange rate on the lending rate results a negative relationship between them with the value of coefficient is $-2,319$. This negative influence of the exchange rate on the lending rate is significant as the value of t-statistics is greater than its corresponding value of t-table. This negative and significant influence shows that when the exchange rate Rupiah against US dollar increases, the banks' lending rate will fall, vice versa. Bhattarai (2011) [3] found the same result that the association between exchange rate and the interest rate is negative and significant. The depreciation of Rupiah against US Dollar in fact causes the banks to decrease their lending rate. It will give a support for the business sector to get more bank loans rather than to buy more US Dollar.

The variable SIBOR has a direct negative and significant influence on the banks' lending rate with the value of coefficient is $-1,239$. This result shows that when there is an increasing of SIBOR in Singapore money market, the banks' lending rate in Indonesia will decrease. In this situation, the increasing of SIBOR will give advantage for the banks to supply more loans for the business sector. The reducing of banks' lending rate will be the opportunity for the business sector to invest more in their business by borrowing money from the banks. Kurniawan (2004) [10] found the same result as this research which in the long run, SIBOR 
influences the lending rate negatively.

The variable BI 7-day (reverse) repo rate as reference rate has a positive and significant influence on the banks' lending rate. The coefficient regression that shows its direct influence is 0,156 . This positive relationship means that if the variable BI 7-day (reverse) repo rate increases, the lending rate will increase, vice versa. It shows that BI 7-day (reverse) repo rate is an effective signal for the banks in the case of determining their lending rate. The strong significant of the relationship between BI 7-day (reverse) repo rate and lending rate shows that the signal rate has been transmitted well to the banking sector in the form of determining the banks' lending rate. When the banks may respond fast to the signal rate and make it as their reference rate, it will support Bank Indonesia in implementing the monetary policy.

\subsection{The Structural Equation 3}

The structural equation 3 is estimated to find out and test the influence of exchange rate $\left(\mathrm{X}_{1}\right)$, SIBOR $\left(\mathrm{X}_{2}\right)$, inflation rate $\left(\mathrm{X}_{3}\right)$ and $\mathrm{BI} 7$-day (reverse) repo rate $(\mathrm{Y})$ on the banks' deposit rate $\left(\mathrm{Z}_{2}\right)$, both simultaneously and partially. The result of estimation is shown in table 4.3 as follows:

Tabel 4.3 The Estimation Result of Structural Equation 3

\begin{tabular}{|c|c|c|c|}
\hline Variables & Coefficient & $\boldsymbol{t}$-statistics & Probability \\
\hline $\mathrm{X}_{1}$ & $-1,811$ & $-3,060$ & 0,006 \\
\hline $\mathrm{X}_{2}$ & $-0,198$ & $-3,351$ & 0,003 \\
\hline $\mathrm{X}_{3}$ & $-0,077$ & $-2,632$ & 0,015 \\
\hline $\mathrm{Y}$ & 0,054 & 2,101 & 0,047 \\
\hline $\mathrm{R}^{2}=0,847$ & F-statistics $=31,895$ \\
$\mathrm{E}_{2}=1-0,847=0,153$ & \multicolumn{2}{l}{} \\
\hline
\end{tabular}

\section{Source: Data processed}

The value of coefficient of determination in the structural equation 3 is 0,847 . It means that about $84 \%$ of the variations in the deposit rate is explained by the exchange rate Rupiah against US Dollar, SIBOR, inflation rate and BI 7 -day (reverse) repo rate while the rest of it about $15 \%$ explained by the factors outside the model. By comparing the value of coefficient determination from structural equation 2 and 3 , it is found that equation 2 has higher $\mathrm{R}^{2}$ value rather than equation 3 . These two equations have the same explanatory variables but different dependent variable. Equation 2 is estimated on the lending rate while equation 3 is estimated on the deposit rate. Those explanatory variables are better to explain the variation of the lending rate rather than the deposit rate.

The overall significance of this model shows that the exchange rate Rupiah against US Dollar, SIBOR, inflation rate and $\mathrm{BI}$ 7-day (reverse) repo rate simultaneously influence the deposit rate. This overall influence is significant as seen at the value of F-statistics that is above its corresponding F-table. All these explanatory variables are very important factors for the banks in determining their deposit rate.

Each explanatory variable in structural equation 3 has a significant influence partially on the banks' deposit rate. The exchange rate Rupiah against US Dollar has a negative influence on the deposit rate with the value of regression coefficient is $-1,811$. This value shows the direct influence of the exchange rate on the deposit rate. It means that when Rupiah depreciates against US Dollar, the banks' deposit rate will decrease. On the opposite, the appreciation of Rupiah against US Dollar will cause an increasing of deposit rate. This result is opposite to the hypothesis where it states that the exchange rate influences positively on the deposit rate. It can be explained that if Rupiah depreciates against US Dollar, there will be a tendency to speculate in the foreign exchange market by buying more US Dollar to gain the different between selling and buying price of US Dollar. To prevent the depreciation of Rupiah, the banks increase the deposit rate so that make the market participants are going to be more interested to save their money in Rupiah deposit. In fact, the result of this model shows an opposite result where the banks' deposit rate will decrease when Rupiah depreciates against US Dollar. The banks concern more on the deposit rate as the cost of third party's fund (saving, time deposit and demand deposit). So, if the banks increase the deposit rate, the cost of fund will increase and it may affect heavily their profitability.

The variable SIBOR shows a negative influence on the banks' deposit rate with the value of regression coefficient is $-0,198$. This value shows how big the direct influence of SIBOR on the deposit rate. It means that when the SIBOR increases, the deposit rate will decrease, vice versa. This result is opposite to the hypothesis which said that the SIBOR influences positively the deposit rate. It can be understood that the local banks need to increase their deposit rate if SIBOR increases as a reflection of what took place in the international money market. In fact, for this period of research, the local banks indeed decrease their deposit rate even though the SIBOR increases. By decreasing the deposit rate, the local banks have no doubt that the domestic fund will flow outside of the country even though the SIBOR increases.

The inflation rate has a negative influence on the banks' deposit rate with the value of regression coefficient is 0,077 . This value shows how big the direct influence of the inflation rate on the banks' deposit rate. It means that the increasing of inflation rate will cause a decreasing of deposit rate, vice versa. The higher inflation rate should be followed by the increasing of deposit to prevent people use their money for consuming more goods and services. This action may prevent inflation rate to increase. Nevertheless, the result of this research shows the opposite one. The banks do not need to worry about the tendency of the savers taking their deposit from the bank because of decreasing the deposit rate. The ability of Bank Indonesia to manage the monetary policy has caused a low inflation rate and stable prices. This situation will prevent the action of speculation by buying more goods now because the expectation increasing prices in the future. So, there will be no reason for the banks to increase the deposit rate when inflation rate increase. Furthermore, the higher deposit rate will increase the banks' cost of third party fund that will influence negatively their profitability. On the contrary, when the inflation rate decreases, the deposit rate will increase. It can 
be explained that the decreasing of inflation rate will motivate people to consume more goods and services that will indeed push the inflation rate. So, the banks respond it by increasing the deposit rate in order to prevent the increasing demand for goods and services.

The variable BI 7-day (reverse) repo rate as a reference policy rate has a positive influence on the banks' deposit rate with the value of regression coefficient is 0,054 . This value shows how big the direct influence of BI 7-day (reverse) repo rate on the deposit rate. It means that if Bank Indonesia as the central bank wants to reduce inflation rate, the BI 7-day (reverse) repo rate will be increased. The increasing of this rate will be sent as a signal to the money market and banking sector to increase their deposit rate too. The BI 7-day (reverse) repo rate becomes a reference for the banks in determining their deposit rate. It shows the direction of monetary policy conducted by Bank Indonesia. The faster the banks can adjust their deposit rate to the reference rate, the more effective the implementation of new reference can be transmitted faster to the money market and banking sector because it adheres as a transactional rate to the instruments of borrowing and lending in the money market. Further, it has shorter maturity (tenor) period such as 7, 14, 21 days and its fold. So, the bank may adjust faster the changing of BI 7-day (reverse) repo rate to the changing of their deposit rate. This result is fit to the hypothesis of this research that expects the positive relationship between BI 7-day (reverse) repo rate and the lending rate

\subsection{The Indirect Influences on the Lending Rate}

The result of estimated model on the lending rate and deposit rate are shown in the Fig. 4.1 below:

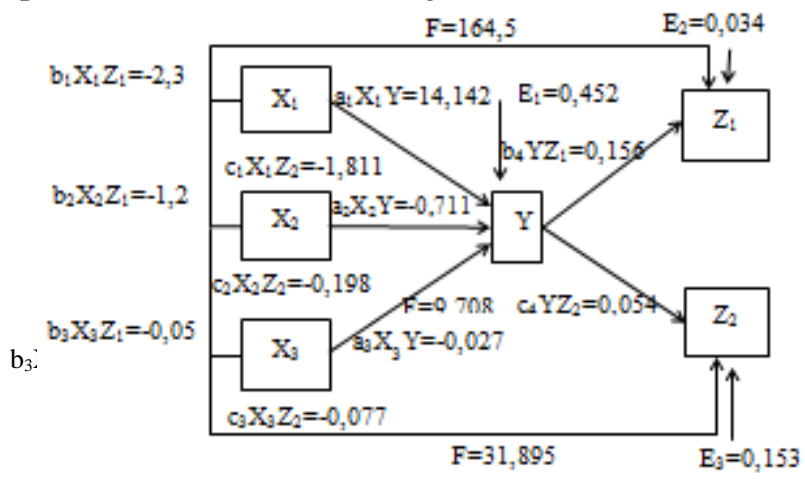

Fig. 4.1 The Result of Estimation

The indirect influence measures the influence of an explanatory variable on the dependent variable through the intervening variable. The first variable that influences the lending rate is the exchange rate. The influence of exchange rate on the lending rate through $\mathrm{BI} 7$-day (reverse) repo rate $\left(\mathrm{X}_{1} \rightarrow \mathrm{Y} \rightarrow \mathrm{Z}_{1}\right)$ is 2,206. This indirect value has changed the direction of relationship between the exchange rate and the lending rate from its direct influence. The direct influence of the exchange rate on the lending rate is negative $(-2,319)$ but the indirect influence turns to be positive influence (2,206). It means that the negative direct influence of depreciation of Rupiah against US Dollar on the deposit rate could be changed by BI 7-day (reverse) repo rate as reference policy rate to be positive indirect influence. So, the determination of reference policy rate by Bank monetary policy. BI 7-day (reverse) repo rate as relatively

Indonesia has an important role toward the influence of exchange rate fluctuation on the determination of lending rate.

The influence of SIBOR on the lending rate through BI 7day (reverse) repo rate $\left(\mathrm{X}_{2} \rightarrow \mathrm{Y} \rightarrow \mathrm{Z}_{1}\right)$ is resulted by the value $-0,11$. This indirect influence still has the same direction as its direct influence but its influence is smaller than the direct one. The existence of BI 7-day (reverse) repo rate as reference policy rate can weaken the influence of SIBOR fluctuation on the determination of lending rate, but it cannot change the direction of relationship between SIBOR and the lending rate.

The influence of inflation rate on the lending rate through BI 7-day (reverse) repo rate $\left(\mathrm{X}_{3} \rightarrow \mathrm{Y} \rightarrow \mathrm{Z}_{1}\right)$ is resulted as the value $-0,004$. This indirect influence still has the same direction as its direct influence but its influence is smaller than the direct one. When Bank Indonesia applies the monetary policy by determining BI 7-day (reverse) repo rate as reference policy rate, the actual inflation rate must be considered as a very important factor. As seen from this result, the determination of BI 7-day (reverse) repo rate once again can weaken the influence of inflation rate on the deposit rate.

\subsection{The indirect Influences on the Deposit Rate}

The variable exchange rate has a negative direct influence on the deposit rate with the value $-1,811$. In fact, when BI 7day (reverse) repo rate exists as an intervening variable, the direction of relationship between them turns to be a positive one. The value of indirect influence of the exchange rate on the deposit rate $\left(\mathrm{X}_{1} \rightarrow \mathrm{Y} \rightarrow \mathrm{Z}_{2}\right)$ is 0,763 . As can be seen here, the determination of BI 7-day (reverse) repo rate may change the direction of influence between the exchange rate and deposit rate. It can be explained that when the Rupiah depreciates against US Dollar, Bank Indonesia can direct the banks to increase their deposit rate by raising BI 7-day (reverse) repo rate. This action can prevent people to buy more US Dollar because the deposit rate increases. Comparing the indirect influence of exchange rate on lending rate and deposit rate, it is found that the indirect influence of exchange rate on the lending rate is bigger than on the deposit rate.

The influence of SIBOR on the deposit rate through BI 7day (reverse) repo rate $\left(\mathrm{X}_{2} \rightarrow \mathrm{Y} \rightarrow \mathrm{Z}_{2}\right)$ is resulted as the value $-0,038$. The direct and indirect influence of SIBOR on the deposit rate has the same direction, which is negative influence but the direct influence is bigger than its indirect one. Once again, BI 7-day (reverse) repo rate as a reference policy rate can weaken the influence of SIBOR on the deposit rate but still do not change the direction of relationship between those variables. The indirect influence of SIBOR on the lending rate is bigger than on the deposit rate.

The influence of inflation rate on the deposit rate through BI 7-day (reverse) repo rate $\left(\mathrm{X}_{3} \rightarrow \mathrm{Y} \rightarrow \mathrm{Z}_{2}\right)$ is quite low as the value resulted is 0,001 . Both the direct and indirect influence of inflation rate on the deposit rate has the same 
direction, which is negative influence but the direct influence is still bigger than the indirect one. Just like the policy rate can weaken the influence of inflation rate on the deposit rate but do not change the direction of relationship between those variables. The indirect influence of inflation rate on the lending rate is bigger than on the deposit rate even though those indirect influences are quite low.

\section{CONCLUSION}

This paper is an empirical research that used monthly series data from September, 2016 to December 2018. Model of Path Analysis is implemented to estimate three structural equations that examine the influence of exchange rate, SIBOR and inflation rate on the lending and deposit rate through BI 7-day (reverse) repo rate as a reference policy rate.

Based on the result of estimation, some conclusions can be composed. First, the exchange rate, SIBOR and inflation rate influence simultaneously and significantly BI 7-day (reverse) repo rate as a reference policy rate but only the exchange rate partially influences BI 7-day (reverse) repo rate. Second, the exchange rate, SIBOR, inflation rate and BI 7-day (reverse) repo rate influence simultaneously and significantly the lending rate but the inflation rate is the only explanatory variable that do not influence significantly the lending rate. The rest of it influences partially and significantly the lending rate. Third, the exchange rate, SIBOR, inflation rate and BI 7-day (reverse) repo rate influence simultaneously and significantly the deposit rate and all these explanatory variables has partial and significant influence on the deposit rate. Fourth, BI 7-day (reverse) repo rate as a reference policy rate in this model becomes an intervening variable that can reduce the influence of each explanatory variables on the lending and deposit rate. Fifth, BI 7-day (reverse) repo rate as a reference policy rate has been transmitted well to the banking sector in the form of lending and deposit rate determination, even though the influence of all explanatory variables is stronger on the lending rate rather than the deposit rate

\section{REFERENCES}

1. Ang, A. and G. Bekaert, "International Asset Allocation with Regime Shifts", The Review of Financial Studies, 15, 2002, pp. $1137-1187$.

2. Ayomi, Sri and Bambang Hermanto, "Mengukur Resiko Sistemik dan Keterkaitan Finansial Perbankan di Indonesia", Buletin Ekonomi Moneter dan Perbankan, 16, 2013, pp. $103-125$.

3. Bhattarai, Keshab, "Impact of Exchange Rate and Money Supply on Growth, Inflation and Interest Rate in the UK", International Journal Monetary Economics and Finance, 4, 2011, pp. $355-371$.

4. Blanchard, Olivier, Macroeconomics, second edition. Prentice Hall, New Jersey, 2000.

5. Chowdhury, Emon Kalyan, "Impact of Inflation on Bank Lending Rate in Bangladesh", Journal of Politics and Governance, 1, 2012, pp. 5 - 13 .

6. Dai, Q. and K.J Singleton, "Specification Analysis of Affine Term Structure Models", Journal of Finance, LV, 2002, pp. 1943 - 1978. variable SIBOR, BI 7-day (reverse) repo rate as a reference

7. Galí, Jordi and Mark Gertler, "Macroeconomic Modeling for Monetary Policy Evaluation", Journal of Economic Perspectives, 21, 2007, pp. $25-45$.

8. Gujarati, Damodar N, Basic Econometrics, McGraw Hill, New York, 2003.

9. Handa, Jagdish, Monetary Economics, Second Edition. Routledge, New York, 2009.

10. Kurniawan, Taufik, "Determinan Tingkat Suku Bunga Pinjaman di Indonesia tahun 1983 - 2002”, Buletin Ekonomi Moneter dan Perbankan, 2004, pp. 437 - 459.

11. Krugman, Paul R. and Maurice Obstfeld, International Economics: Theory and Policy, Addison Wesley, 2000.

12. Mandeij, Dennij, "Hubungan Antara BI Rate dengan Suku Bunga Deposito dan Pinjaman Bank Umum", Jurnal Pembangunan Ekonomi dan Keuangan Daerah, 6, 2011, pp. $46-57$.

13. Mishkin, Frederic S., The Economics of Money, Banking and Financial Markets, Addison Wesley Higher Education, 2006.

14. Özdemir, Durmus and Harald Schmidbauer, "Resiko Tingkat Bunga di Pasar Keuangan Turki pada Periode Waktu yang Berbeda", Buletin Ekonomi Moneter dan Perbankan, 2014, pp. $195-217$.

15. Rose, Peter S. and Sylvia C. Hudgins, Bank Management and Financial Services, McGraw Hill International Edition, New York, 2010.

16. Samuelson, Paul A. and William D. Nordhaus, Economics, Nineteenth Edition. McGraw Hill Irwin, New York, 2010

17. Saunders, Anthony and Garnett M. Millon, Financial Institutions Management: a Risk Management Approach, McGraw Hill International Edition, New York, 2008.

18. Siringoringo, Renniwaty, "Karakteristik dan Fungsi Intermediasi Perbankan Indonesia", Buletin Ekonomi Moneter dan Perbankan, 15, 2012, pp. 61 - 83.

19. Sunyoto, Danang, Model Analisis Jalur untuk Riset Ekonomi, Yrama Widya, Bandung, 2012

\section{AUTHORS PROFILE}

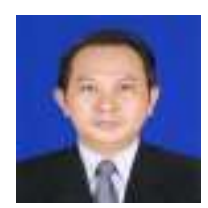

Dennij Mandeij received his Bachelor of Economics (B.Ec) from Gadjah Mada University, Yogyakarta in 1996 and continued to the Post Graduate Program at the same university and received Master of Science (M.Sc.) in Economics in 1999. He completed a Short Courses Training on the Entrepreneurship Teaching from Humber College, Toronto, Canada in 2014. He is now a lecturer in Faculty of Economics and Business, Sam Ratulangi University, Manado. His research works has primarily been in the areas of Monetary Economics and Entrepreneurship. One of his research works was collaboration with a researcher from Humber College and has published the result as an occasional paper in the website of International Development Institute, Humber College, Canada. His research papers have been published in the Jurnal Pembangunan Ekonomi dan Keuangan Daerah and Jurnal Berkala Ilmiah Efisiensi. He also holds a Certified Business Coach (CBC) from Top Coach Indonesia.

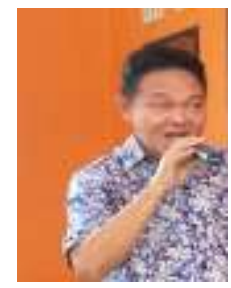

Vekie A. Rumate received his Bachelor of Economics (B.Ec.) from Sam Ratulangi University, Manado in 1986. He continued his education to the post graduate program at Gadjah Mada University, Yogyakarta and received Master of Science in Economics in 1992. He has completed his Doctoral degree in Economics from Hasanudin University, Makassar in 2008. He is now a lecturer in Faculty of Economics and Business, Sam 
International Conference on Recents Advancements in Engineering and Technology (ICRAET-18) |15th and 16th March 2019|Siddhartha Institute of Technology \& Sciences, Telangana, India.

Ratulangi University, Manado. His research works has primarily been in the areas of Macroeconomics and Public Economics. He has published his research papers in some Journals such as, Jurnal Pembangunan Ekonomi dan Keuangan Daerah and Jurnal Berkala Ilmiah Efisiensi. He is a former expert staff of development issues in North Sulawesi Province. He is also a member of Indonesia Bachelor of Economics Association, branch of Manado.

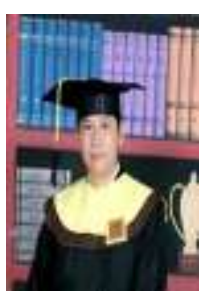

Wensy F.I Rompas received his Bachelor of Economics (B.Ec.) from Sam Ratulangi University, Manado in 2002. He has completed his Master degree in Management of Development Resources from Sam Ratulangi University in 2011. He is now a lecturer in Faculty of Economics and Business, Sam Ratulangi University, Manado. His research works has primarily been in the areas of Regional Development Planning and Agriculture Economics. He has published his research papers in some Journals such as, Jurnal Pembangunan Ekonomi dan Keuangan Daerah and Jurnal Berkala Ilmiah Efisiensi. He is a member of Indonesia Bachelor of Economics Association, branch of Manado 